\title{
PENERAPAN MODEL TRIPLE HELIX DAN KEUNGGULAN BERSAING PADA UKM INDUSTRI KREATIF DI KABUPATEN SIDOARJO
}

\author{
Endah Supeni Purwaningsih \\ Fakultas Ekonomi \& Bisnis Universitas Wijaya Putra Surabaya \\ Email : endahsupeni@uwp.ac.id
}

\begin{abstract}
Permasalahan yang dihadapai pelaku Industri Kreatif di Jawa Timur Khusunya Kabupaten Sidoarjo dihadapkan pada permasalahan yang kini bukan lagi sebuah masalah permodalan, melainkan sebuah permasalahan daya saing sebuah produk. Permasalahan Industri Kreatif olahan makanan di Kecamatan Tanggulangin yang menjadi potensi dan ciri khas Kabupaten Sidoarjo adalah Inovasi produk yang masih belum memiliki daya saing, dikarenakan produksi hasil olahan makanan seperti sate bandeng, emping pedas masih diproduksi dan dikemas secara manual dan tradisional. Tujuan dari program ini adalah mencari model atau metode peningkatan daya saing Pelaku Industri Kreatif khusunya di Kecamatan Tanggulangin dalam meningkatkan kemampuan dan pengetahuan pelaku industri pada usaha pengemasan dan inovasi cita rasa tanpa meninggalkan ciri khas dari produk mereka. Metode yang digunakan adalah membuat model yang dapat diterapkan untuk mengatasi permasalahan pelaku industri dengan memadukan Competitive Advantage dan Triple Helix. Hasil dari program ini adalah menemukan model peningkatan daya saing pelaku industri olahan makanan di Kecamatan Tanggulangin Kabupaten Sidoarjo dengan Competitive Advantage dan Triple Helix yang mensinergikan Para Pelaku Industri dan Peran ABG (Akademisi, Bisnis dan Pemerintah). Hal tersebut menjadi bahan perhatian dan pertimbangan pemerintah Kabupaten Sidoarjo untuk membuat sebuah program yang bisa mendorong para pelaku Industri Kreatif bisnis berinovasi dengan tetap memegang tradisinya.
\end{abstract}

Kata kunci: Competitive Advantage, Triple Helix dan Pertumbuhan Industri Kreatif.

\section{PENDAHULUAN}

Pembangunan suatu wilayah sangat terkait dengan pembangunan ekonomi daerah. Memasuki era otonomi daerah muncul kebutuhan akan instrumen dan metode dalam perencanaan pembangunan yang lebih sesuai dengan kebutuhan pemerintah dan masyarakat di daerah. Hal ini menyebabkan terjadi pegeseran dari pendekatan "membangun di daerah" menuju orientasi "membangun daerah". Dimana proses pembangunan ekonomi harus berasal dari inisiatif masyarakat di daerah tersebut, atau pembangunan daerah didominasi oleh aspirasi daerah sendiri. Pembangunan ekonomi daerah merupakan suatu proses di mana pemerintah daerah dan masyarakat dalam mengelola sumber daya yang ada dan membentuk suatu pola kemitraan antara pemerintah daerah dengan sektor swasta sebagai upaya menciptakan lapangan kerja baru dan merangsang perkembangan pertumbuhan ekonomi dalam wilayah tersebut (Mudrajat, 2004, h.120).

Industri Kreatif merupakan sektor industrial yang berasal dari pemanfaatan kreatifitas, ketrampilan, dan bakat individu untuk menciptakan kesejahteraan dan lapangan pekerjaan melalui penciptaan dan pemanfaatan daya kreatifitas individu, ketrampilan, dan bakat yang mempunyai potensi kekayaan, serta penciptaan peluang pekerjaan (Santoso, Agnessia Puteri, 2014).

Berbeda dengan karakteristik industri pada umumnya, Industri Kreatif merupakan kelompok industri yang terdiri dari berbagai jenis industri yang masing-masing memiliki keterkaitan dalam proses pengeksploitasian ide atau kekayaan intelektual (intellectual property) menjadi nilai ekonomi tinggi yang dapat menciptakan kesejahteraan dan lapangan pekerjaan.

Ekonomi, Sosial, dan Budaya 1356 
Kabupaten Sidoarjo merupakan salah satu Kabupaten di Jawa Timur yang berada di antara dua sungai besar pecahan Kali Brantas, yakni Kali Mas dan Kali Porong, sehingga dikenal dengan sebutan Kota Delta (Kemalekaw, 2013). Ekonomi menjadi salah satu sendi kehidupan yang tidak mungkin ditinggalkan di Kabupaten Sidoarjo (Moch. Shofwan, Sri Murtini, 2012). Dalam Rencana Tata Ruang Wilayah Kabupaten Sidoarjo Tahun 2009-2029 dijelaskan bahwa kawasan yang ditetapkan sebagai kawasan strategis di wilayah Kabupaten Sidoarjo, salah satunya adalah kawasan industri kecil dan menengah, dan kreatif yang berada di Kecamatan Tanggulangin. Oleh karena itu, dibutuhkan pengembangan industri kreatif tas dan koper untuk menunjang sebagai penetapan kawasan strategis.

Berkembangnya potensi bisnis di Kota Sidoarjo sempat memberikan perbedaan cara pandang tentang makna entrepreneurship pada masyarakat kota. Entrepreneurship yang sering dimaknai sebagai sebuah usaha atau sebuah profesi, kini berubah menjadi gaya hidup tersendiri yang melekat pada masyarakat modern. Kenyataan ini dialami langsung pada masyarakat modern yang sekaligus sebagai pelaku bisnis di Kota Sidoarjo, sebab banyak diantara mereka yang merangkap pekerjaan inti dengan berbisnis di rumah, baik itu bisnis secara fisik atau pun secara online.

Permasalahan yang dihadapai pelaku Industri Kreatif di Jawa Timur khususnya Kabupaten Sidoarjo sendiri dihadapkan pada sebuah permasalahan yang kini bukan lagi sebuah masalah permodalan, melainkan sebuah permasalahan daya saing sebuah produk, dimana para pelaku Industri Kreatif belum dapat meningkatkan daya saing dalam memproduksi produknya sehingga bernilai jual tinggi. Daya saing pelaku Industri Kreatif terkendala dengan kurangnya penguatan pengetahuan dan akses pasar yang luas untuk dapat bersaing baik di pasar dalam negeri maupun di pasar global. Hal ini mengakibatkan pelaku Industri Kreatif tidak dapat berkembang dan meningkatkan produktifitasnya secara maksimal.

Permasalahan Industri Kreatif olahan makanan yang menjadi potensi ciri khas
Kabupaten Sidoarjo yang dipaparkan pada penelitian ini adalah Inovasi produk yang masih belum memiliki daya saing, dikarenakan produksi hasil olahan makanan seperti sate bandeng, emping pedas masih diproduksi dan dikemas secara manual dan tradisional. Kurangnya pengetahuan dan kemampuan maupun tetap memegang cara tradisi nenek moyang mereka terdahulu dengan cara tardisional menjadi faktor penghambat untuk berdaya saing agar mampu memberikan sebuah kemasan maupun cita rasa yang lebih inovatif. Hal tersebut menjadi bahan perhatian dan pertimbangan pemerintah Kabupaten Sidoarjo untuk membuat sebuah program yang bisa mendorong para pelaku Industri Kreatif bisnis berinovasi dengan tetap memegang tradisinya.Sehingga olahan makanan ciri khas Kabupaten Sidoarjo tersebut dapat berkembang baik di pasar lokal maupun internasional.

Permasalahan Industri Kreatif yang telah dijelaskan diatas pada dasaranya bisa diatasi secara perlahan apabila peran pemerintah dalam menjalankan fungsi pemberdayaannya dapat lebih optimal untuk meningkatkan produktifitas pelaku Industri Kreatif di Indonesia khususnya Kabupaten Sidoarjo. Berdasarkan hasil observasi yang peneliti lakukan di lapangan, permasalahan yang hampir serupa ditemukan seperti yang dikemukakan oleh Kepala Dinas Koperasi dan Industri Kreatif Provinsi Jawa Timur diatas, khususnya Industri Kreatif di Kecamatan Sidoarjo yang menjadi lokasi peneliti dalam melakukan penelitian. Peneliti mengidentifikasi bagaimana pemberdayaan yang dilakukan oleh Pemerintah Kabupaten Sidoarjo melalui Dinas Koperasi Industri Kreatif dan Perindutrian Perdagangan Kabupaten Sidoarjo dalam memberdayakan potensi Industri Kreatif di Kecamatan Sidoarjo agar dapat meningkatkan keberdayaannya sehingga mampu menghadapi permasalahan-permasalahannya. Competitive Advantage dapat diperoleh dari kemampuan perusahaan untuk mengelola dan memanfaatkan sumber daya dan modal yang dimilkinya. Perusahaan yang mampu menciptakan Competitive Advantage akan memiliki kekuatan untuk bersaing

Ekonomi, Sosial, dan Budaya 1357 
dengan perusahaan lainnya karena produknya akan tetap memiliki kekuatan untuk bersaing dengan perusahaan lainnya karena produknya akan tetap diminati pelanggan. Dengan demikian Competitive Advantage memilki pengaruh positif terhadap peningkatan Pertumbuhan Industri Kreatif perusahaan.

Triple Helix adalah metode pembangunan kebijakan berbasis inovasi. Teori ini yang mengungkapkan pentingnya penciptaan sinergi tiga kutub yaitu Akademisi, Bisnis dan Pemerintah di Indonesia dikenal sebagai konsep ABG. Triple Helix yang pertama yakni Akademisi, sebagai bagian dari komunitas cendekiawan di dalam Lembaga Pendidikan Tinggi dan lembaga penelitian memiliki peranan yang besar dalam mengembangkan ekonomi kreatif. Peranan akademi / intelectual inovasi dan ide-ide kreatif, merupakan bagian yang terpenting dari Industri Kreatif. Untuk mewujudkan hal tersebut peranan akademis sangat dibutuhkan dalam berkreatif dan menciptakan produk unggulan.Upaya melibatkan akademis dalam pengembangan Industri Kreatif mutlak diperlukan. Tugas dan peranan akademis dalam menunjang keberhasilan Industri Kreatif suatu daerah adalah: Partisipasi dalam pembangunan dan pemeliharaan potensi Industri Kreatif. Penyediaan ide-ide inovasi dan tenaga kerja. Penyediaan sumber-sumber informasi. Jadi disimpulkan bahwa peran akademis / intelectual berpengaruh terhadap Pertumbuhan Industri Kreatif. Triple Helix yang ke dua yakni business atau pengusaha, merupakan pelaku usaha, investor dan pencipta teknologi baru serta merupakan konsumen industri kreatif. Peranan pengusaha terhadap keberhasilan Industri Kreatif dapat dilihat dari tingkat kepuasan yang akan berpengaruh terhadap jumlah pesanan yang meningkat. Triple Helix yang ke tiga yakni Pemerintah (government), merupakan suatu sistem struktur dan organisasi dari berbagai macam fungsi yang dilaksanakan atas dasar-dasar tertentu untuk mewujudkan tujuan Negara.Tak dapat dipungkiri bahwa peran pemerintah sangat berperan dalam menciptakan dan menunjang tingkat keberhasilan perekonomian suatu daerah atau negara. Dalam menyeimbangkan pelaku lain yakni swata atau dunia usaha, institusi pendidikan dan profesional maka peran pemerintah sebagai fasilitator, regulator, dan motivator. Implementasi tugas dan peranan pemerintah dalam keberhasilan Industri Kreatif adalah : Pembina, pendorong dan pengatur dan pengendali pembangunan serta mewujudkan iklim yang kondusif bagi Industri Kreatif. Penataan dan penyediaan fasilitas penunjang.

\section{LANDASAN TEORI Triple Helix}

Teori mengenai Triple Helix pada awalnya dipopulerkan oleh Etzkowitz \& Leydersdorff sebagai metode pembangunan kebijakan berbasis inovasi. Teori ini yang mengungkapkan pentingnya penciptaan sinergi tiga kutub yaitu akademisi, bisnis dan pemerintah di Indonesia dikenal sebagai konsep ABG. Dari teorinya, tujuan dari ABG adalah pembangunan ekonomi berkelanjutan berbasis ilmu pengetahuan. Dari sinergi ini diharapkan terjadi sirkulasi ilmu pengetahuan berujung pada inovasi, yaitu yang memiliki potensi ekonomi, atau kapitalisasi ilmu pengetahuan (knowledge capital). Triple Helix sebagai aktor utama harus selalu bergerak melakukan sirkulasi untuk membentuk knowledge spaces, ruang pengetahuan dimana ketiga aktor sudah memiliki pemahaman \& pengetahuan yang setara, yang akan mengarahkan ketiga aktor ini untuk membentuk concensus space, ruang kesepakatan dimana ketiga aktor ini mulai membuat kesepakatan dan komitmen atas suatu hal yang akhirnya akan mengarahkan kepada terbentuknya innovation spaces, ruang yang dapat dikemas menjadi produk kreatif bernilai ekonomis

Model pengembangan ekonomi kreatif yang dikembangkan untuk Indonesia berupa bangunan yang terdiri dari komponen pondasi, 5 pilar, dan atap yang saling menguatkan sesuai dengan fungsinya masing-masing. Penjelasan komponenkomponen bangunan ekonomi kreatif adalah sebagai berikut: 


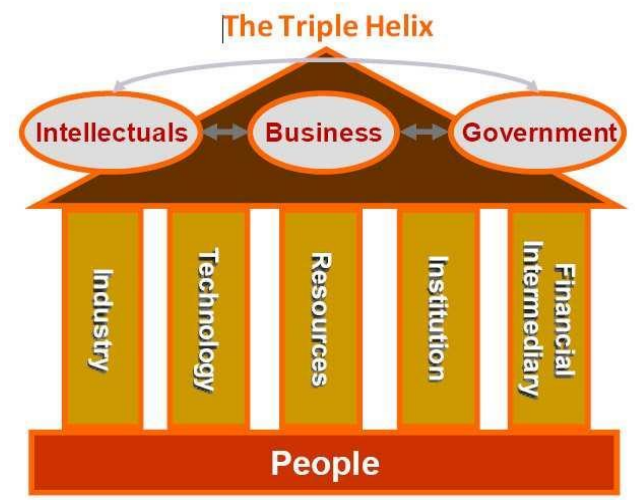

Sumber: Etzkowitz, H. The endless transition: A "triple helix"

\section{PONDASI:}

People (Sumber Daya Insani), aset utama dari industri kreatif yang menjadi ciri hampir semua subsektor industri kreatif.

2. LIMA PILAR UTAMA yang harus diperkuat dalam mengembangkan industri kreatif adalah:

1). Industry (Industri) yaitu kumpulan dari perusahaan yang bergerak di dalam bidang industri kreatif.

2). Technology (Teknologi) yaitu enabler untuk mewujudkan kreativitas individu dalam bentuk karya nyata.

3). Resources (Sumber Daya) yaitu input selain kreativitas dan pengetahuan individu yang dibutuhkan dalam proses kreatif, misal: sumber daya alam, lahan

4). Institution (Institusi) yaitu tatanan sosial (norma, nilai, dan hukum) yang mengatur interaksi antara pelaku perekonomian khususnya di bidang industri kreatif.

5). Financial Intermediary yaitu lembaga penyalur keuangan

3. ATAP:

Bangunan ekonomi kreatif ini dipayungi oleh interaksi triple helix yang terdiri dari Intellectuals (Intelektual), Business (Bisnis), dan
Government (Pemerintah) sebagai para aktor utama penggerak industri kreatif.

1). Intellectual, kaum intelektual yang berada pada institusi pendidikan formal, informal dan non formal yang berperan sebagai pendorong lahirnya ilmu dan ide yang merupakan sumber kreativitas dan lahirnya potensi kreativitas insan Indonesia

2). Business, pelaku usaha yang mampu mentransformasi kreativitas menjadi bernilai ekonomis

3). Government, pemerintah selaku fasilitator dan regulator agar industri kreatif dapat tumbuh dan berkembang.

Pemerintah dan pemerintahan mempunyai pengertian yang berbeda. Pemerintah merujuk kepada organ atau alat perlengkapan, sedangkan pemerintahan menunjukkan bidang tugas atau fungsi. Dalam arti sempit pemerintah hanyalah lembaga eksekutif saja. Sedangkan dalam arti luas, pemerintah mencakup aparatur negara yang meliputi semua organorgan, badan-badan atau lembagalembaga, alat perlengkapan negara yang melaksanakan berbagai kegiatan untuk mencapai tujuan negara. Dengan demikian pemerintah dalam arti luas adalah semua lembaga negara yang terdiri dari lembaga-lembaga legislatif, eksekutif dan yudikatif.

Dalam arti sempit pemerintahan adalah segala kegiatan, fungsi, tugas dan kewajiban yang dijalankan oleh lembaga eksekutif untuk mencapai tujuan negara. Pemerintahan dalam arti luas adalah segala kegiatan yang terorganisir yang bersumber pada kedaulatan dan kemerdekaan, berlandaskan pada dasar negara, rakyat atau penduduk dan wilayah negara itu demi

Ekonomi, Sosial, dan Budaya 1359 
tercapainya tujuan negara. Di samping itu dari segi struktural fungsional pemerintahan dapat didefinisikan pula sebagai suatu sistem struktur dan organisasi dari berbagai macam fungsi yang dilaksanakan atas dasar-dasar tertentu untuk mewujudkan tujuan negara. (Jurnal Haryanto dkk, 1997 : 2-3). Secara deduktif dapat disimpulkan bahwa pemerintah dan pemerintahan dibentuk berkaitan dengan pelaksanaan berbagai fungsi yang bersifat operasional dalam rangka pencapaian tujuan negara yang lebih abstrak, dan biasanya ditetapkan secara konstitusional. Berbagai fungsi tersebut dilihat dan dilaksanakan secara berbeda oleh sistem sosial yang berbeda, terutama secara ideologis. Hal tersebut mewujud dalam sistem pemerintahan yang berbeda, dan lebih konkrit terwakili oleh dua kutub ekstrim masing-masing rezim totaliter (sosialis) dan rezim demokratis. Substansi perbedaan keduanya terletak pada perspektif pembagian kekuasaan negara (pemerintah). Pemencaran kekuasaan (dispersed of power), menurut Leslie Lipson, merupakan salah satu dari lima isu besar dalam proses politik (Josef Riwu Kaho, 2001 : 1). Pemerintahan daerah merupakan konsekuensi pelaksanaan pemencaran kekuasaan itu.

Triple Helix dapat mempengaruhi Pertumbuhan Industri Kreatif, hal ini peran intelektual, bisnis dan pemerintah saling bersinergi dalam meningkatkan Pertumbuhan Industri Kreatif (jurnal Puja Astawa; 2010)

Dalam ekonomi, sistem "Triple helix" menjadi payung yang menghubungkan antara Cendekiawan (Intellectuals), Bisnis (Business), dan Pemerintah (Government) dalam kerangka bangunan ekonomi kreatif. Di mana ketiga helix tersebut merupakan aktor utama penggerak lahirnya kreativitas, ide, ilmu pengetahuan, dan teknologi yang vital bagi tumbuhnya industri kreatif. Hubungan yang erat, saling menunjang, dan bersimbiosis mutualisme antara ke-3 aktor tersebut dalam kaitannya dengan landasan dan pilar-pilar model ekonomi berkesinambungan dalam meningkatkan Pertumbuhan Industri Kreatif (Leydesdorff, L. and $\mathrm{H}$. Etzkowitz. 1996).

Nowotny et al (2001) mengutarakan enam indikator sehingga Triple Helix yang ada di dalam industri dapat menjadi sumber berkesinambungan. Keenam indikator tersebut antara lain Regulasi dan Proteksi, Pengetahuan, Penelitian dan Teknologi, Pemberdayaan masyarakat, Etika bisnis, dan Corporate responsibility.

\section{Hipotesis Penelitian}

Berdasarkan uraian pada kerangka pemikiran penelitian tersebut di atas maka hipotesis yang dikemukakan adalah sebagai berikut :

1. Diduga Competitive Advantage berpengaruh positif dan signifikan terhadap Pertumbuhan Industri Kreatif.

2. Diduga peran Triple Helix berpengaruh positif dan signifikan terhadap Pertumbuhan Industri Kreatif.

\section{METODE PENELITIAN}

Definisi operasional adalah segala sesuatu yang menjadi objek pengamatan suatu penelitian yang bedasarkan sifat-sifat atau hal-hal yang didefinisikan atau diamati. Definisi operasi setiap variabel yang dipergunakan dalam penelitian ini adalah sebagai berikut :

I. Competitive Advantage (X1)

Competitive Advantage diartikan sebagai strategi benefit dari perusahaan yang melakukan kerjasama untuk menciptakan Competitive Advantage yang lebih efektif dalam pasarnya, dengan indikator-indikator (Barney, 1991 danGrant, 1991):

Ekonomi, Sosial, dan Budaya 1360 
a. Nilai-nilai dari perusahaan yang langka (valuable) X1.1 adalah sumber daya yang menciptakan nilai bagi suatu perusahaan dengan mengeksploitasi peluang-peluang atau menetralisir ancaman-ancaman dalam lingkungan eksternal perusahaan.

b. Sulit ditiru (imitability) X1.2 adalah Sumber daya yang bernilai dan langka tersebuthanya dapat menjadi sumber Competitive Advantage yang berkesinambungan jika perusahaan lain yang tidak memilikinya, tidak dapat memperoleh kompetensi tersebut.

c. Daya tahan perusahaan terhadap persaingan (durabilitas) X1.3 adalah Sumber daya perusahaan memiliki Competitive Advantage ketika dapat menghindar dari pesaing, lamanya ketahanan sumber daya dan penurunan kemampuan dari waktu ke waktu, sehingga menyebabkan tingkat kemunduran Competitive Advantage

d. Tingkat kemudahan untuk menyamai aset-aset strategis yang dimiliki oleh perusahaan (transferability) X1.4 adalah Competitive Advantage diperoleh ketika perusahaan memiliki kemudahan untuk memperoleh akses gampang kepada sumber daya dan kemampuan yang dimiliki oleh pesaing bahkan di atasnya pesaing, baik dari sisi biaya atau keuntungan nilai tambah didasarkan pada teknologi proses yang ada tersedia.

\section{II.Triple Helix (X2)}

Konsep Triple Helix digunakan untuk menjelaskan hubungan ketiga elemen (business, intellectuals, and government), yang dapat memberikan gambaran mengenai koordinat dari simbiosis (irisan) dari masing-masing elemen. Dalam Triple Helix, masing masing elemen merupakan entitas yang berdiri sendiri, memiliki perannya masing-masing meskipun mereka bersinergi, dengan indikator - indikator (Nowotny et al 2001):

A. Akademis X2.1

1) Transmisi Pengetahuan $X 2.1 .1$ adalah ilmu pengetahuan merupakan faktor kunci keberhasilan dalam peningkatan perkembangan Industri Kreatif

2) Penelitian dan Teknologi $X 2.1 .2$ adalah merupakan kegiatan sentral dalam pengembangan inovasi dan teknologi

B. Business X2.2

1) Etika Bisnis $X 2.2 .1$ adalah merupakan cara untuk melakukan kegiatan bisnis, yang mencakup seluruh aspek yang berkaitan dengan individu, perusahaan dan juga masyarakat. Etika Bisnis dalam suatu perusahaan dapat membentuk nilai, norma dan perilaku wirausaha serta pengusaha dalam membangun hubungan yang adil dan sehat dengan pelanggan.

2) Corporate Responsibility X2.2.2 adalah sebagai bisnis yang dilakukan secara transparan dan terbuka serta berdasarkan pada nilai-nilai moral dan menjunjung tinggi rasa hormat.

C. Goverment X2.3

1) Regulasi dan Proteksi $X 2.3 .1$ adalah pemerintah membuat aturan-aturan demi ketertiban dalam pemenuhan kebutuhan dan kepentingan serta kebijakan pemerintah untuk melindungi industri.

2) Pemberdayaan Masyarakat X2.3.2 adalah Layanan konsultasi diberikan dengan cara membuka layanan konsultasi bagi masyarakat dalam mengenai pelaksanaan usahanya.

III.Pertumbuhan Industri Kreatif (Y)

Pertumbuhan Industri Kreatif merupakan ukuran prestasi yang diperoleh dari aktifitas proses pemasaran secara menyeluruh dari sebuah perusahaan atau organisasi. Dengan indikator-indikator (Anggraini, 2008):

a. Kreatifitas Individu (Y.1)

b. Ketrampilan (Y.2)

c. Talenta (Y.3) 
Populasi adalah wilayah generalisasi yang terdiri atas : obyek atau subjek yang mempunyai kualitas dan karakteristik tertentu yang ditetapkan oleh peneliti untuk dipelajari dan kemudian ditarik kesimpulannya. (Sugiyono, 2004:72). Populasi dalam penelitian ini adalah semua Industri Kreatif di Kecamatan Tanggulangin Kabupaten Sidoarjo.

Sampel adalah suatu himpunan bagian (subset) dari unit populasi yang telah tersedia. Teknik dasar yang digunakan untuk pada PLS adalah resampling dengan Bootestrapping (Geisser \& Stone, 2001). Ukuran sampel dalam PLS dengan perkiraan sebagai berikut:

> Sepuluh kali jumlah indikator formatif (mengabaikan indikator refleksif)

$>$ Sepuluh kali jumlah jalur struktural (structural paths) pada inner model.

$>$ Sample size kecil 30 - 50 atau sampel besar lebih dari 200.

Sampel dalam penelitian ini adalah pimpinan dan pengelola yang mewakili dari Industri Kreatif Kecamatan Tanggulangin yang mewakili 30 responden.

\section{TeknikAnalisis dan Pengujian Hipotesis}

Data yang diperoleh dalam penelitian perlu dianalisis agar dapat ditarik suatu kesimpulan yang tepat. Oleh karena itu perlu ditetapkan teknik analisis yang sesuai dengan tujuan penelitian yang hendak dicapai, juga untuk menguji kebenaran hipotesis.

Teknik analisis data pada penelitian ini menggunakan Partial Least Square (PLS) dengan bantuan software Smart PLS 2.0 M3. PLS merupakan sebuah metode untuk mengkonstruksi model-model yang dapat di ramalkan ketika faktor-faktor terlalu banyak. PLS dikembangkan pertama kali oleh Herman Wold sebagai metode umum untuk mengestimasi path model yang menggunakan variabel laten dengan multiple indikator. PLS juga merupakan factor indeterminacy metode analisis yang powerful karena tidak mengasumsikan data harus dengan pengukuran skala tertentu, jumlah sampel kecil. Awalnya Partial Least Square berasal dari ilmu sosial (khusus ekonomi), Herman Wold, 1996). Model ini dikembangkan sebagai alternatif untuk situasi dimana dasar teori pada perancangan model lemah atau indikator yang tersedia tidak memenuhi model pengukuran refleksif. PLS selain dapat digunakan sebagai konfirmasi teori, juga dapat digunakan untuk membangun hubungan yang belum ada landasan teorinya atau untuk pengujian proposal (Anggraini, 2010).

\section{Pengujian Hipotesis}

Pengujian hipotesis $(\beta$ dan $Y)$ dilakukan dengan metode resampling boot strap yang dikembangkan oleh Geisser dan Stone. Statistik uji yang digunakan adalah statistik $t$ atau uji $t$, dengan hipotesis statistik sebagai berikut:

a. model

Hipotesis statistik untuk outer

i. $\quad \mathrm{H} 0: \lambda \mathrm{i}=0$ lawan

ii. $\quad \mathrm{H} 1: \lambda \mathrm{i} \neq 0$

b. Hipotesis untuk inner model : variabel laten eksogen terhadap endogen

i. $\quad \mathrm{H} 0: \lambda \mathrm{i}=0$ lawan

ii. $\quad \mathrm{H} 1: \lambda \mathrm{i} \neq 0$

c. Penerapan metode resampling, memungkinkan berlakunnya data terdistribusi bebas (distribution free), tidak memerlukan asumsi distribusi normal, serta tidak memerlukan sampel yang besar (sampel minimum 30). Pengujian dilakukan dengan t-test, bilamana diperoleh $\mathrm{p}$-value $\leq 0,1$ alpha 10\%). Maka disimpulkan signifikan, dan sebaliknya. Bilamana hasil pengujian hipotesis pada outer model signifikan, hal ini menunjukan bahwa indikator dipandang dapat digunakan sebagai instrumen pengukur variabel laten. Sedangkan bilamana hasil pengujian pada inner model adalah signifikan maka dapat diartikan bahwa terdapat pengaruh yang bermakna variabel laten terhadap variabel laten lainnya.

\section{HASIL DAN PEMBAHASAN Uji Reliability}

Ekonomi, Sosial, dan Budaya 1362 
Composite reliability adalah indeks yang menunjukkan sejauh mana suatu alat pengukur dapat dipercaya untuk diandalkan. Bila suatu alat dipakai dua kali untuk mengukur gejala yang sama dan hasil pengukuran yang diperoleh relatif konsisten maka alat tersebut reliabel. Dengan kata lain, reliabilitas menunjukkan suatu konsistensi alat pengukur dalam gejala yang sama. Hasil selengkapnya dapat dilihat pada tabel berikut:

Tabel 1. Reliabilitas Data:

\begin{tabular}{|c|c|}
\hline & Composite Reliability \\
\hline $\begin{array}{c}\text { COMPETITIVE } \\
\text { ADVANTAGE (X1) }\end{array}$ & 0.595635 \\
\hline $\begin{array}{c}\text { PERTUMBUHAN } \\
\text { INDUSTRI } \\
\text { KREATIF (Y) }\end{array}$ & 0.776337 \\
\hline $\begin{array}{c}\text { TRIPLE HELIX } \\
\text { (X1) }\end{array}$ & 0.824494 \\
\hline
\end{tabular}

Sumber: data diolah

Reliabilitas konstruk yang diukur dengan nilai composite reliability, konstruk reliabel jika nilai composite reliability di atas 0,70 maka indikator disebut konsisten dalam mengukur variabel latennya. Hasil pengujian menunjukkan bahwa konstruk (variabel) Triple Helix dan Pertumbuhan Industri Kreatif memiliki nilai composite reliability lebih besar dari 0,7. Sehingga reliabel. Sedang untuk variabel Competitive Advantage memiliki nilai composite reliability lebih kecil 0,7 maka reliabilitasnya rendah.

Pengujian terhadap model struktural dilakukan dengan melihat nilai R-Square yang merupakan uji goodness-fit model. Pengujian inner model dapat dilihat dari nilai R-square pada persamaan antar variabel latent. Nilai $\mathrm{R}^{2}$ menjelaskan seberapa besar variabel eksogen (independen/bebas) pada model mampu menerangkan variabel endogen (dependen/terikat)

\section{Uji Kausalitas}

Tabel 2. Uji Kausalitas

\begin{tabular}{|c|c|c|c|c|c|}
\hline & $\begin{array}{l}\text { Koef } \\
\text { isien } \\
\text { Path } \\
(\mathrm{O})\end{array}$ & $\begin{array}{l}\text { Sam } \\
\text { ple } \\
\text { Mea } \\
\text { n } \\
(\mathrm{M})\end{array}$ & $\begin{array}{l}\text { Stan } \\
\text { dard } \\
\text { Devi } \\
\text { ation } \\
\text { (ST } \\
\text { DEV } \\
\text { ) }\end{array}$ & $\begin{array}{l}\text { Stan } \\
\text { dard } \\
\text { Erro } \\
\mathrm{r} \\
\text { (ST } \\
\text { ERR } \\
\text { ) }\end{array}$ & $\begin{array}{l}\mathrm{T} \\
\text { Statisti } \\
\text { cs } \\
(\mid \mathrm{O} / \mathrm{ST} \\
\mathrm{ERR} \mid)\end{array}$ \\
\hline $\begin{array}{l}\text { COMPETI } \\
\text { TIVE } \\
\text { ADVANTA } \\
\text { GE (X1) - } \\
>\text { PERTU } \\
\text { MBUHAN } \\
\text { INDUSTR } \\
\text { I } \\
\text { KREATIF } \\
\text { (Y) }\end{array}$ & $\begin{array}{l}0.51 \\
5923\end{array}$ & $\begin{array}{l}0.56 \\
5492\end{array}$ & $\begin{array}{l}0.23 \\
9383\end{array}$ & $\begin{array}{l}0.23 \\
9383\end{array}$ & $\begin{array}{l}2.1552 \\
16\end{array}$ \\
\hline $\begin{array}{l}\text { TRIPLE } \\
\text { HELIX } \\
\text { (X2) - } \\
\text { >PERTU } \\
\text { MBUHAN } \\
\text { INDUSTR } \\
\text { I } \\
\text { KREATIF } \\
\text { (Y) }\end{array}$ & $\begin{array}{l}0.21 \\
5220\end{array}$ & $\begin{array}{l}0.18 \\
7251\end{array}$ & $\begin{array}{l}0.18 \\
2642\end{array}$ & $\begin{array}{l}0.18 \\
2642\end{array}$ & $\begin{array}{l}1.1783 \\
75\end{array}$ \\
\hline
\end{tabular}

Sumber : data diolah

Berdasarkan tabel diatas menunjukkan bahwa:

1. Competitive Advantage (X1) berpengaruh terhadap Pertumbuhan Industri Kreatif $(\mathrm{Y})$ dengan koefisien path sebesar 0,5159, dapat diterima dimana nilai $\mathrm{T}$-Statistic $=2,1552$ lebih besar dari nilai $\mathrm{Z} \alpha=0,10$ $(10 \%)=1,645$, maka Signifikan (Positif)

2. TRIPLE HELIX (X2) tidak berpengaruh terhadap Pertumbuhan Industri Kreatif (Y) dengan koefisien path sebesar 0,2152, tidak dapat diterima dimana nilai $\mathrm{T}$-Statistic $=$ 1,1783 lebih kecil dari nilai $\mathrm{Z} \alpha=$ $0,10(10 \%)=1,645$, maka Non Signifikan (Positif)

\section{Pembahasan}

Ekonomi, Sosial, dan Budaya 1363 


\section{Pengaruh Competitive Advantage Terhadap Pertumbuhan Industri Kreatif}

Berdasarkan hasil penelitian yang telah dilakukan diperoleh hasil bahwa Competitive Advantage berpengaruh terhadap Pertumbuhan Industri Kreatif dapat diterima.

Penelitian ini didukung oleh Ginanjar Suendro, (2011) yang menyatakan bahwa Competitive Advantage dan inovasi secara simultan mempunyai pengaruh yang signifikan dan positif terhadap variabel dependen Pertumbuhan Industri Kreatif Batik. Dengan demikian hipotesis pertama diterima. Secara parsial (Uji T) ternyata dari hasil penelitian membuktikan bahwa tidak semua indikator dari variabel independen yaitu variabel Competitive Advantage dan inovasi mempunyai pegaruh yang positif dan signifikan terhadap variabel dependen Pertumbuhan Industri Kreatif Batik. Untuk Hipotesis pertama yang menyatakan bahwa Competitive Advantage berpengaruh positif terhadap Pertumbuhan Industri Kreatif, dapat diterima karena pada penelitian ini didapatkan hasil bahwa Competitive Advantage mempunyai pengaruh yang positif terhadap Pertumbuhan Industri Kreatif.

Hal ini sesuai dengan pendapat Potter (1997) tentang pengaruh Competitive Advantage terhadap kesuksesan produk, dinyatakan bahwa pengaruh Competitive Advantage dapat mempengaruhi Pertumbuhan Industri Kreatif, serta menumbuhkan prioritas membeli konsumen dan pembelian ulang konsumen. Sebuah Competitive Advantage itu harus berani suatu berkreativitas, agar dimata konsumen terlihat berbeda atau unik dari yang lainnya dan dalam penyampaian pesan pun harus jelas dan terarah. Dan agar dapat menciptakan daya tarik tersendiri terhadap produk tersebut, sehingga akan terciptanya minat konsumen atau wisatawan untuk berkunjung di wisata tersebut.

Berdasarkan hasil uraian tersebut maka dengan adanya Competitive Advantage yang menarik maka akan daat meningkatkan Pertumbuhan Industri Kreatif.

\section{Pengaruh Triple Helix Terhadap Pertumbuhan Industri Kreatif}

Berdasarkan hasil penelitian yang telah dilakukan diperoleh hasil bahwa Triple Helix berpengaruh terhadap Pertumbuhan Industri Kreatif. Tidak dapat diterima.

Untuk Hipotesis kedua yang menyatakan bahwa Triple Helix berpengaruh positif terhadap Pertumbuhan Industri Kreatif, tidak dapat diterima karena pada penelitian ini didapatkan hasil bahwa dimensi Triple Helix (Goverment) tidak mempunyai pengaruh terhadap Pertumbuhan Industri Kreatif.

Hal ini bisa disebabkan karena dimensi pemerintah tidak begitu besar dalam memberi kotribusi Pertumbuhan Industri Kreatif. Sebagian besar ekonom menerima kenyataan bahwa tatanan legal politik dibutuhkan untuk menciptakan kondisi dasar untuk akumulasi dan menegakkan institusi yang nantinya difungsikan untuk mengatur kompetisi dan disiplin pasar, sistem finansial yang efektif, pasar tenaga kerja dan proteksi atas hak properti kapitalis yang terlegitimasi (Dunford, 2000: 148). Dan indikator pemerintah dalam pemberdayaan masyarakat hanya memberikan sedikit di dalam Triple Helix. Meskipun dimensi akademis dan business di dalam Triple Helix memberikan kontribusi yang positif di dalam indikatornya. Walaupun pengelola atau pemilik industri percaya kalau Triple Helix adalah kesinergi ABG (Akademis. Business, Goverment) yang terkenal di dalam industri di Indonesia saat ini, tapi pemilik industri juga memiliki tingkat privasi dalam mengelola Pertumbuhan Industri Kreatif tersebut. Jadi walaupun tingkat Triple Helix meningkat tidak akan mempengaruhi Pertumbuhan Industri Kreatif.

Penelitian ini didukung oleh Suparwoko,(2010) yang menyatakan bahwa Triple Helix dan inovasi secara simultan tidak mempunyai pengaruh yang signifikan dan positif terhadap variabel dependen Pertumbuhan Industri Kreatif Gula Aren di Kota Pacitan. Dengan demikian hipotesis kedua tidak diterima. Secara parsial (Uji T) ternyata dari hasil penelitian membuktikan bahwa tidak semua indikator dari variabel independen yaitu variabel Triple Helix dan inovasi tidak mempunyai pegaruh yang positif dan signifikan terhadap variabel

\begin{tabular}{l|l} 
Ekonomi, Sosial, dan Budaya & 1364
\end{tabular} 
dependen Pertumbuhan Industri Kreatif Gula Aren di Kota Pacitan.

Triple Helix dapat diwujudkan apabila ke tiga ABG saling berkesinambungan dalam memenuhi harapan pengelola atau pemilik industri, dimana mereka akan puas terhadap inovasi atau ide gagasannya tersebut. Triple Helix akan timbul apabila konsumen telah merasakan kepuasan karena telah menjalankan atau menggunakan inovasi. Oleh karena apabila ke tiga $A B G$ ini juga berperan penting untuk menjadi industri yang kreative.

\section{KESIMPULAN DAN SARAN}

\section{Kesimpulan}

Setelah melakukan penelitian, pengumpulan dan menganalisis terhadap data-data yang telah diperoleh dari responden, maka kesimpulan dan saran dalam penelitian ini adalah sebagai berikut :
1. Competitive Advantage mampu memberikan kontribusi yang berarti terhadap Pertumbuhan Industri Kreatif.

2. Triple Helix kurang dapat memberikan kontribusi yang berarti terhadap Pertumbuhan Industri Kreatif.

\section{Saran}

Adapun saran yang dapat disampaikan oleh peneliti adalah :

1. Meningkatkan lagi Pertumbuhan Industri Kreatif misalnya untuk beriklan pada televisi lokal dan memperbanyak banner yang dipasang di jalan sehingga mesyarakat dapat lebih banyak yang melihat dan akan mengetahui tentang Industri Kreatif di benak masyarakat.

2. Dalam menjaga dan mempertahankan produk atau jasa yang sudah ada, Industri Kreatif juga dapat memberikan Competitive Advantage yang berkualitas produk dan menambah variasi produknya.

3. Keterbatasan penelitian di dalam objek Industri Kreatif di Kecamatan Tanggulangin Kabupaten Sidoarjo.
Adam Jr, Everett .E, Ronald .J. Ebert, 1992, Production and Operation Management, Prentice Hall International.Inc, Fifth Edition, New Jersey.

Anderson, J.C. and D.W. Gerbing, 1988, Structural Equation Modeling in Practice : A Review and Recommended Two-Step Approach, Psycological Bulletin. 103 (3) : 41123.

Assauri, Sofyan, 2004, Manajemen Pemasaran, Cetakan Ketujuh, Rajawali Pers, Jakarta

Bentler, P.M. and C.P. Chou, 1987, Practical Issue in Structural Modeling, Sociological Methods and Research. 16 (1) : 78-117

Cravens, David W, 1996, Pemasaran Strategis, Terjemahan, Jilid 1, Edisi Keempat, Penerbit Erlangga, Jakarta.

Ferdinand, Augusty, 2002, Structural Equation Modeling Dalam Penelitian Manajemen, Edisi 2, Penerbit BP UNDIP, Semarang.

Hair, J.F. et. al. [1998], Multivariate Data Analysis, Fifth Edition, Prentice-Hall International, Inc., New Jersey.

Hartline, Michael D. and O.C. Ferrell [1996], "The Management of CustomerContact Service Employees : An Empirical Investigation", Journal of Marketing. 60 (4) : 52-70.

Kotler, Philip, 1997, Manajemen Pemasaran, Terjemahan, Jilid I, Edisi Keenam, Penerbit Erlangga Jakarta.

---------, 2004, Manajemen Pemasaran, Edisi Milenium, Indeks, Jakarta.

----------, dan Gary Amstrong, 1997, DasarDasar Pemasaran.Jilid 1. Penerbit Prenhallindo, Jakarta.

Lamb, Hair dan Mc. Daniel, 2001, Pemasaran, Buku 1, Penerbit Salemba Empat.

Lupiyoadi Rambat, 2001 Manajemen Pemasaran Jasa Teori Dan Praktik. Penerbit Salemba Empat

Peter, Paul J. And Olson, Jerry C, 1996, Consumer Behavior : Perilaku Konsumen dan Strategi Pemasaran, Edisi Keempat, Jilid I, Penerbit Erlangga, Jakarta.

Ekonomi, Sosial, dan Budaya 1365 
Sugiyono, 2004, Metode Penelitian Bisnis, Penerbit CV. Alfabeta, Sidoarjo

Swastha, Basu 1999, Manajemen Pemasaran, analisa perilaku konsumen, Edisi pertama,, cetakan ketiga Yogyakarta.

---------, 2000, Azas-Azas Marketing, Edisi Ketiga, Penerbit Liberty Yogyakarta.

-----------, dan Tani Handoko, 2000, Manajemen Pemasaran, Analisa Perilaku Konsumen, Edisi Pertama, Cetakan Ketiga Yogyakarta.

Tabachnick B.G., 1996, Using Multivariate Statistics, Third Edition, HarperCollins CollegePublisher.

Tandjung, Widjaja, Jenu, 2004, Marketing Strategy, Edisi Pertama, Cetakan Pertama, Spirit 2004, Surabaya.

Tjiptono Fandy, 2000, Manajemen Jasa, Edisi Kedua, Penerbit Andi Offset, Yogyakarta.

Leydesdorff, L. and H. Etzkowitz. 1996. Emergence of a Triple Helix of University-Industry-Government Relations, Science and Public Policy 23 (5): 279-286.

Leydesdorff, L. 2003. The mutua information of university-industrygovernment relations: An indicator of the Triple Helix dynamics. Scientometrics 58 (2): 445-467

Leydesdorff, L. 2008. Configurational Information as Potentially Negative Entropy: The Triple Helix Model.

Entropy 10 (4): 391-410. 